\title{
ОСОБЛИВОСТІ ЗДІЙСНЕННЯ ТА ФІНАНСУВАННЯ ІННОВАЦЙНОЇ ДІЯЛЬНОСТІ НА ЗАЛІЗНИЧНОМУ ТРАНСПОРТІ
}

\author{
Панченко Н.Г., к.е.н., доцент (УкрДУЗТ)
}

\begin{abstract}
Удосконалення засобів та методів пошуку, аналізу та збереження інформащії, розвиток інновачійної інфраструктури створюють підгрунтя для становлення та формування інновачійних утворень. Інновачія характеризується, насамперед, результативністю, яка визначається економічним ефектом від покращання (підвищення) експлуатачійно-економічних показників нової техніки та прогресивної технологї. Ефект може бути одержаний за рахунок як розширення асортименту та підвищення якості продукції (послуг), економії матеріальних ресурсів, скорочення трудових витрат, підвищення продуктивності праці, так $i$ зниження шкідливих викидів в навколишнє середовище та ін. На залізничний транспорт припадає більше половини всього вантажообігу, тому з розвитком залізниць пов'язані інші галузі економіки. Крім того, залізничний транспорт $\epsilon$ досить матеріаломістка та енерговитратна галузь, де впровадження інновачій з метою економії витрат може дати значний ефект, пери за все, в масштабі країни. Фінансування проектів у необхідних обсягах покликано забезпечити сталий інновачійний розвиток залізничного транспорту, нарощення науковотехнічного потенціалу галузі з метою підвищення конкурентоспроможності залізниць на ринку транспортних послуг. Для налагодження чіткої системи фінансування необхідно визначати основні джерела фінансування або їх сукупність, розробити механізм акумуляиіі грошових надходжень та раціональні методи інвестування інноваційних проектів, а також механізм контролю за використанням коштів та оичінку його ефективності.
\end{abstract}

Ключові слова: інноваційна діяльність, залізничний транспорт, інноваційний розвиток, фінансування інноваційної діяльності, інвестування інноваційних проектів

\section{ОСОБЕННОСТИ ОСУЩЕСТВЛЕНИЯ И ФИНАНСИРОВАНИЯ ИННОВАЦИОННОЙ ДЕЯТЕЛЬНОСТИ НА ЖЕЛЕЗНОДОРОЖНОМ TРАНСПОРТЕ}

\author{
Панченко Н.Г., к.э.н., доцент (УкрГУЖТ)
}

\begin{abstract}
Усовершенствование средств и методов поиска, анализа и сохранения информации, развитие инновачионной инфраструктуры создают основу для становления и формирования инновационных образований. Инновация характеризуется, прежде всего, результативностью, которая определяется экономическим эффектом от улучшения (повышения) эксплуатаџионно-экономических показателей новой техники и прогрессивной технологии. Эффект может быть получен за счет как расширения ассортимента и повышения качества продукции (услуг), экономии материальных ресурсов, сокращении трудовых затрат, повышение производительности труда, так и снижения вредных выбросов в окружаюшую среду и др. На железнодорожный транспорт приходится более половины всего грузооборота, поэтому с развитием железных дорог связаны другие отрасли экономики. Кроме того, железнодорожный транспорт является достаточно
\end{abstract}


материалоемкой и энергозатратной отраслью, где внедрение инноваций с иелью экономии затрат может дать существенный эффект, прежде всего, в масштабе страны. Финансирование проектов в необходимых объемах призвано обеспечить устойчивое инновационное развитие железнодорожного транспорта, наращивание научно-технического потенџиала отрасли с иелью повышения конкурентоспособности железных дорог на рынке транспортных услуг. Для налажсивания четкой системь финансирования необходимо определять основные источники финансирования или их совокупность, разработать механизм аккумулящии денежных поступлений $u$ рациональные методы инвестирования инновачионных проектов, а также механизм контроля за использованием средств и оченку его эффективности.

Ключевые слова: инновационная деятельность, железнодорожный транспорт, инновационное развитие, финансирование инновационной деятельности, инвестирования инновационных проектов

\title{
ESPECIALLY THE IMPLEMENTATION AND FINANCING OF INNOVATIVE ACTIVITIES IN RAILWAY TRANSPORT
}

\author{
Panchenko N.G., Ph.D. in Economics, associate Professor (USURT)
}

Improvement of means and methods of search, analysis and preservation of information, development of innovative infrastructure provide the basis for the development of innovative entities. Innovation is characterized primarily by performance, which is determined by the economic effect of the improvement (increase) of operational and economic performance of new equipment and progressive technologies. The effect can be obtained by expanding the range and improving the quality of products (services), conserve material resources, reduce labor costs, increase productivity, and reduce harmful emissions into the environment etc. On railway transport accounts for more than half of the total turnover, therefore, with the development of Railways linked to other sectors of the economy. In addition, rail transport is rather materialintensive and energy-intensive industry, where the introduction of innovations to save costs can give a significant effect, primarily on a national scale. Project financing in the necessary amounts is intended to ensure sustainable innovative development of rail transport, strengthening scientific and technical potential of the industry with the aim of increasing the competitiveness of Railways on the transport market. To establish a clear financing system it is necessary to determine the main sources of funding or a combination of them, to develop a mechanism for the accumulation of cash receipts and rational methods of investing of innovative projects, as well as the mechanism of control over the use of funds and the evaluation of its effectiveness.

Keywords: innovation activity, railway transport, innovative development, financing of innovation, innovative investment projects

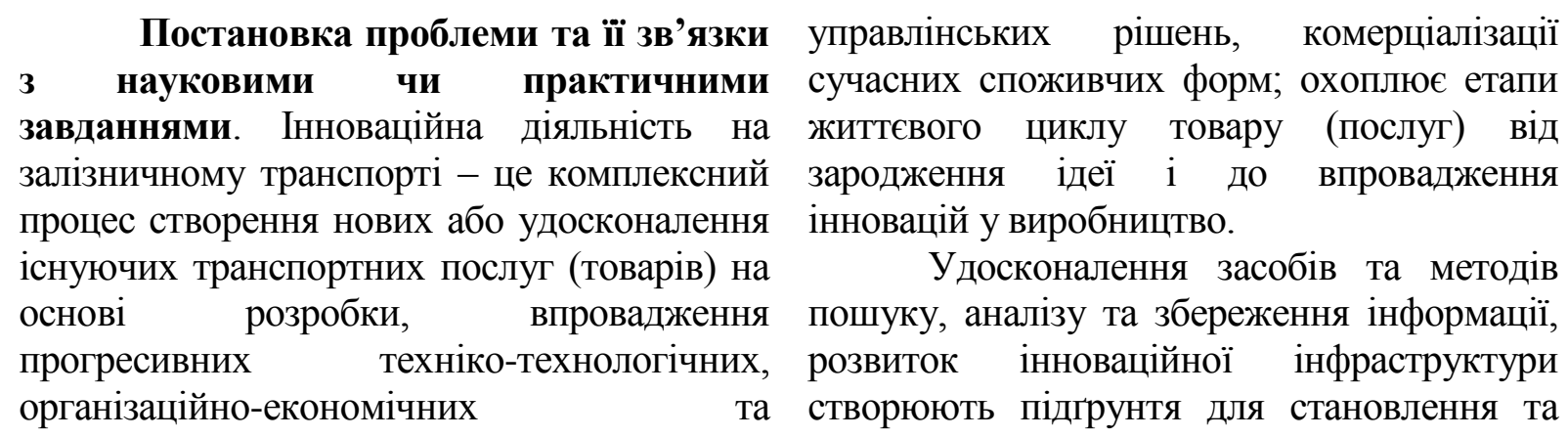

Вісник економіки транспорту і промисловості № 59, 2017 
формування інноваційних утворень. Інновація характеризується, насамперед, результативністю, яка визначається економічним ефектом від покращання (підвищення) експлуатаційно-економічних показників нової техніки та прогресивної технології. Ефект може бути одержаний за рахунок як розширення асортименту та підвищення якості продукції (послуг), економії матеріальних ресурсів, скорочення трудових витрат, підвищення продуктивності праці, так i зниження шкідливих викидів в навколишне середовище та ін.

Результат інноваційної діяльності залежить від фінансового забезпечення інновацій. Наявність грошових коштів, які спрямовуються на інновації, є необхідною умовою розвитку таких процесів, що, в свою чергу, підвищує науково-технічний потенціал галузі; технічний рівень рухомого складу та об'єктів інфраструктури і, тим самим, технічні та технологічні можливості залізниць з надання конкурентоспроможних транспортних послуг. Саме тому, на нашу думку, зазначена проблематика є достатньо актуальною.

Аналіз останніх досліджень i публікацій. Інноваційна діяльність $\epsilon$ пріоритетним напрямком наукових досліджень на протязі тривалого періоду часу. Тематика доробку вчених варіюється від визначення сутності інновацій та інноваційного процесу до спроб міждисциплінарного поєднання теорії інноватики 3 інвестиційною наукою, теоріями конкуренції та конкурентоспроможності, стратегічним менеджментом. Серед найбільш актуальних робіт з теми дослідження, на нашу думку, слід виокремити науковий доробок таких вчених, як: В. Дикань [1, 2, 6], В. Зубенко [1, 3], Л. Калініченко [4], О. Кірдіна [2, 5, 7], I. Назаренко, Ю. Уткіна [2], А. Толстова [6] та iH.

Виділення невирішених частин загальної проблеми. Не дивлячись на значну кількість наукових праць, які стосуються напрямку даного дослідження, автор вважає, що питання щодо дослідження особливостей здійснення та фінансування інноваційної діяльності саме на залізничному транспорті не знайшли достатнього відображення у роботах науковців.

Формування цілей статті (постановка завдання). Саме тому метою даної статі $\epsilon$ дослідження особливостей здійснення та фінансування інноваційної діяльності на залізничному транспорті.

Виклад основного матеріалу дослідження. В останні роки на залізничному транспорті інноваційна діяльність спрямовується на впровадження інформаційних технологій, логістичних принципів організації перевезень, нових видів сервісного обслуговування 3 наданням комплексу супутніх робіт, що має на меті створення транспортних послуг високої якості та нових споживчих характеристик.

Критеріями оцінки ефективності інноваційних процесів виступають технікоекономічні показники, які порівнюють витрати на таку діяльність 3 доходами від реалізації інновацій на практиці. В зв'язку $з$ тим, що інноваційна діяльність забезпечує сталий економічний розвиток та постійне зростання прибутку на підприємствах, то дохідність виступає не як мета інноваційної діяльності, а як важлива умова підвищення рівня та якості транспортних послуг, статусу залізниць та їх ролі в економіці країни та іiї регіонів.

Інноваційна діяльність залізниць визначається економічною політикою галузі, складовою частиною якої $\epsilon$ інноваційна, що передбачає: формування стратегіï; розробку інноваційних проектів та програм; удосконалення структури управління; впровадження енергозберігаючих та екологічно безпечних технологій тощо; орієнтація на потреби споживачів кінцевої транспортної продукції.

Планування інновацій повинно враховувати обгрунтоване формуванні основних напрямків інноваційній діяльності відповідно до встановленої мети розвитку

Вісник економіки транспорту і промисловості № 59, 2017 
залізниць, можливостей ресурсного забезпечення та попиту на залізничні перевезення. Планування інновацій забезпечує деталізацію цілей інноваційного процесу, доведення їх до окремих підрозділів та виконавців, розподіл завдань між учасниками інноваційних проектів, визначення складу необхідних ресурсів, узгодження термінів реалізації окремих робіт.

Планування необхідне, в першу чергу, для забезпечення результативності та підвищення ефективності інноваційних процесів і покликано вирішувати наступні завдання: активізація діяльності, конкретизація цілей та доведення їх до окремих виконавців; постановка наукових, технічних та виробничих задач, вирішення яких забезпечує досягнення мети; взаємозв'язок між виконавцями інноваційного проекту та координація їх діяльності; розрахунок обсягів фінансових, матеріальних та інших видів ресурсів, необхідних для реалізації проектів; контроль виконання термінів їх реалізації.

Слід зазначити, що планування інновацій повинно враховувати специфіку складових залізничного транспорту рухомого складу та інфраструктури, масштабність робіт та їх результативність, а також терміни реалізації інноваційних проектів.

Основні напрямки інновацій на залізничному транспорті наведені на рис. 1.

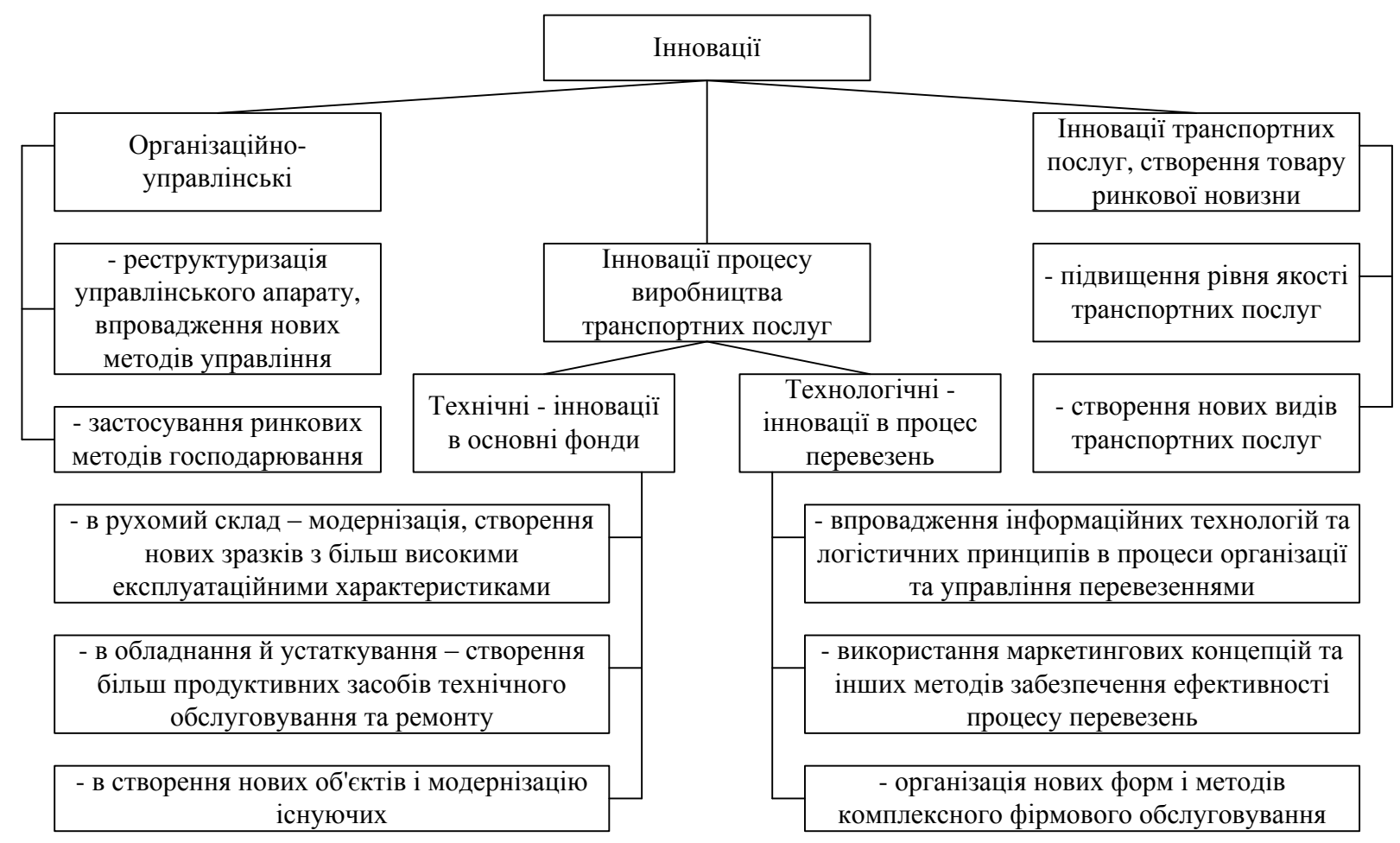

Рис. 1. Основні напрями інноващій на залізничному транспорті

Прискорений розвиток залізничного транспорту як необхідна умова функціонування потребує подальшого наукового обгрунтування ефективного інвестування інновацій та їх впровадження в процес перевезень. Відповідно до
Концепції розвитку залізничного транспорту передбачається технічне та технологічне переозброєння галузі, впровадження нових транспортних засобів, збільшення потужності рухомого складу, комфортабельності пасажирських вагонів, а

Вісник економіки транспорту і промисловості № 59, 2017 
також оптимізація транспортної мережі та створення міжнародних транспортних коридорів.

Інноваційні проекти мають бути зорієнтовані на проблеми формування та ефективного функціонування залізничнотранспортного комплексу, удосконалення тарифної політики, обгрунтування перспективних параметрів перевізного процесу та його технічних засобів, створення прогресивних технологій, вибір раціональної структури транспортної мережі, формування транспортних коридорів, розробку принципово нових систем управління. Найбільш вагомим напрямком в розробці проектів $\epsilon$ впровадження інформаційних технологій 3 метою створення єдиної системи комунікацій залізничного транспорту, яка буде інтегруватися в світову інформаційну мережу.

Основні інноваційні напрямки розвитку залізничного транспорту визначаються Концепцією та програмою реструктуризації на залізничному транспорті України, Концепцією реформування транспортного сектора України та іншими нормативними документами, які визначають перспективи розвитку галузі.

Крім того, стратегічним завданням інноваційної політики $\epsilon$ створення конкурентоспроможних транспортних послуг як на внутрішньому, так i на зовнішньому ринках; для цього необхідна розробка та реалізація інноваційних продуктів. Успіх реалізації інновацій гарантується при дотриманні інтересів всіх учасників процесу, в тому числі й інвесторів, які забезпечують фінансову підтримку проектів.

Найбільш вагомими напрямками інноваційних розробок $є$ наступні:

- модернізація ліній, які лімітують пропускну спроможність;

- приведення технічних засобів i транспортної мережі у відповідність міжнародним стандартам;

забезпечення швидкого та

безпечного руху поїздів;

- прискорення виконання всіх операцій з обробки вагонів на сортувальних станціях;

- створення умов для здійснення інтермодальних перевезень;

$$
\text { вдосконалення організації }
$$

вантажопотоків на початкових та кінцевих стадіях

- модернізація та створення нових зразків рухомого складу (потужних та економічних локомотивів, вантажних вагонів великої місткості та пасажирських вагонів підвищеної комфортності);

- впровадження в перевізний процес інформаційних технологій та логістичних принципів транспортування;

- посилення ремонтної бази рухомого складу та розвиток колійного господарства;

- електрифікація залізничних колій;

- удосконалення засобів сигналізації, централізації, блокування та зв'язку.

Інноваційна діяльність має супроводжуватись експертизою економічної ефективності проектів, щоб визначити ті 3 них, де мають бути зосереджені всі види ресурсів для гарантованої реалізації пріоритетних ідей. Для їх генерації необхідно проводити дослідження процесів функціонування та розвитку залізничного транспорту як головної ланки транспортної системи. Провідна роль відводиться інформатизації процесу перевезень, створенню єдиної системи комунікацій на транспорті. Значна увага приділяється включенню ряду вітчизняних комунікацій в міжнародні транспортні коридори.

Об'єктом впровадження інновацій є комбіновані перевезення, що можуть взаємодіяти 3 аналогічними мережами іноземних країн.

Інвестиційна діяльність залізниць повинна підтримуватись i 3 боку держави шляхом прямого фінансування інновацій 3 державного та місцевих бюджетів. Джерелами розробки інновацій поряд 3 традиційними можуть виступати також

Вісник економіки транспорту і промисловості № 59, 2017 
нетрадиційні: інвестиційна підтримка фінансово-промислових груп, податкове кредитування та ін. Перспективним джерелом коштів може бути взаємне інвестування за участю широких верств населення, а також інвестиції зарубіжних партнерів, для чого слід розвивати на залізничному транспорті мережу спеціалізованих фінансово-кредитних інститутів, належну інфраструктуру ринку цінних паперів та інші заходи 3 метою створення привабливого клімату для реального та фінансового інвестування.

Система фінансування інновацій повинна базуватись на таких принципах: чітке спрямування грошових коштів на головні напрямки інноваційної діяльності; універсальність та множина джерел фінансування (в тому числі нетрадиційних); достатність (забезпеченість) фінансових ресурсів для всіх пріоритетних напрямків інноваційної діяльності; гнучкість та мобільність грошових потоків як за обсягами фінансування, так і за термінами; прозорість (контрольованість) грошових потоків на всіх напрямках інноваційної діяльності.

Система фінансування інновацій на залізничному транспорті має свою специфіку, яка визначається особливістю проектів, що характеризуються значною капіталоємністю, тривалістю очікування результатів, трудомісткістю відтворення основних фондів та ін.

Інвестиційна діяльність залізниць повинна підтримуватися і з боку держави шляхом прямого фінансування інновацій 3 державного та місцевих бюджетів. Джерелами розробки інновацій поряд 3 традиційними можуть виступати також нетрадиційні: інвестиційна підтримка фінансово-промислових груп, податкове кредитування та інше (рис. 2).

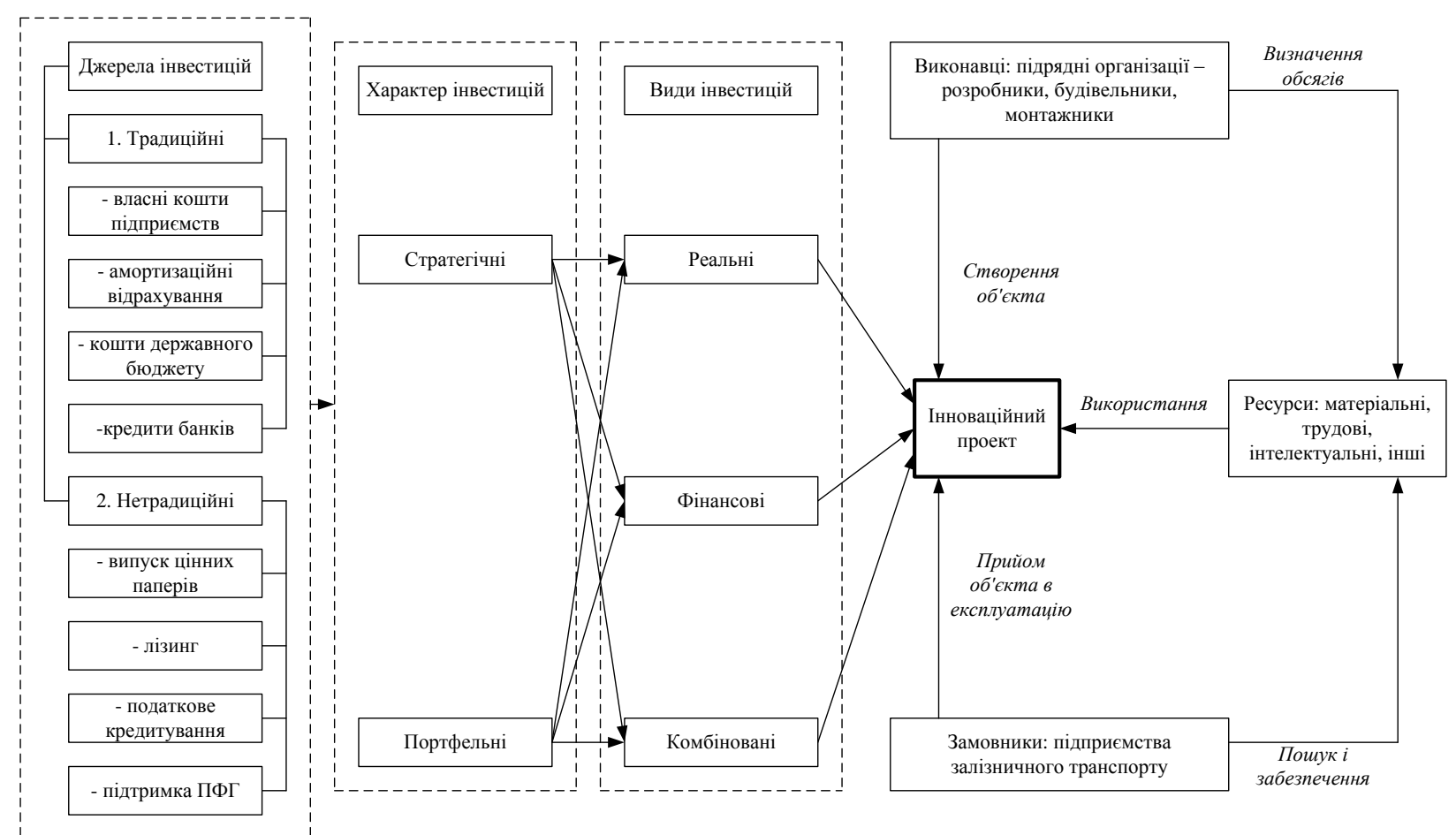

Рис. 2. Інвестиційне забезпечення інновачійного процесу залізничного транспорту

Перспективним джерелом коштів може бути взаємне інвестування за участю широких верств населення, а також інвестиції зарубіжних партнерів, для чого слід розвивати на залізничному транспорті мережу спеціалізованих фінансовокредитних інститутів, належну інфраструктуру ринку цінних паперів та 
інші заходи 3 метою створення привабливого клімату для реального та фінансового інвестування.

Фінансування інноваційної

діяльності $\epsilon$ досить складним механізмом, який постійно розвивається i удосконалюється. В умовах планової економіки фінансування інновацій здійснюється за рахунок бюджету, цільових фондів і власних коштів підприємств.

В умовах ринкової економіки кількість джерел фінансування інновацій суттєво збільшилась, серед яких основними можна вважати:

- бюджетні асигнування (державні та місцеві);

- кошти спеціальних позабюджетних фондів;

- власні кошти підприємств (прибуток, амортизаційні відрахування);
- кредитні ресурси державних інвестиційних банків;

- фінансові ресурси спеціалізованих кредитно-фінансових інститутів інвестиційних фондів та компаній, фінансових компаній, інвестиційних відділів комерційних банків, страхових компаній, пенсійних фондів та ін.;

- іноземні інвестиції промислових та комерційних фірм.

Однак фінансова забезпеченість інновацій на залізничному транспорті недостатня і гальмує інноваційний процес. Для його інтенсифікації необхідно застосувати ряд заходів, які зацікавлюють інвесторів в фінансуванні інновацій, та надати ряд пільг підприємствам, які б стимулювали інноваційну діяльність (рис. 3).

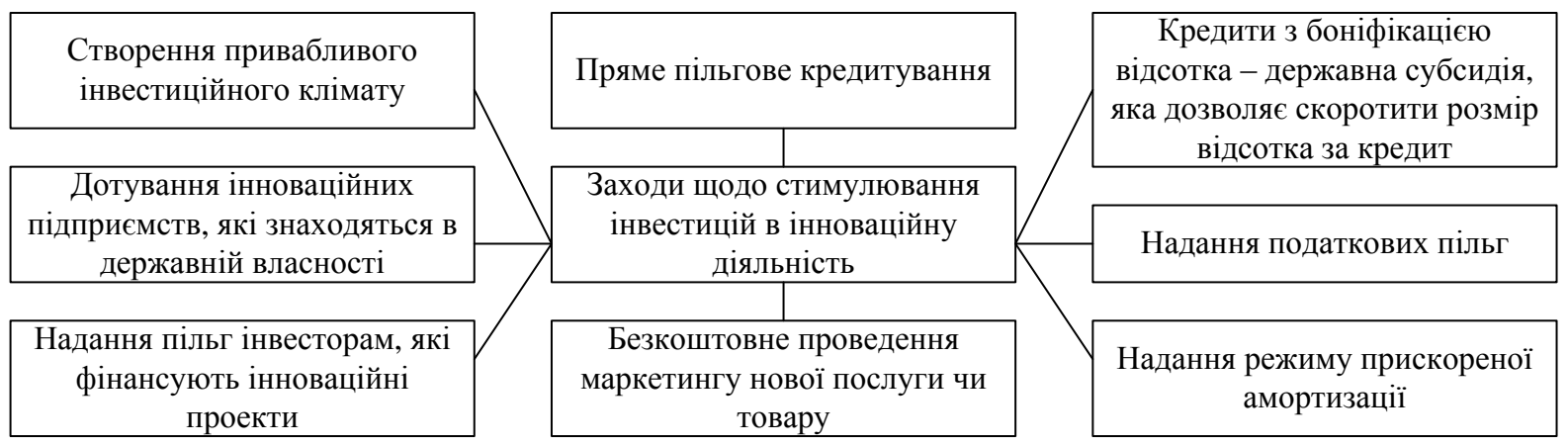

Рис. 3. Методи стимулювання інвестищій в інноващійну діяльність залізнищь

Обсяг необхідних фінансових ресурсів для реалізації інноваційних проектів визначається за кошторисом, який складається для кожного з них як поетапно, так і з розподілом за роками та кварталами. Це дає змогу визначити загальну величину коштів для всього проекту.

Узагальнюючим фінансового забезпечення інновацій $\epsilon$ фінансовий план, де відбиваються грошові доходи та витрати. Фінансовий план підприємства складається 3 чотирьох самостійних розділів.

В першому ведеться облік доходів та надходження коштів; включаються всі фінансові ресурси підприємства, крім тих, які одержані від банків та держави. До складу показників входять прибуток: виконання науково-дослідних та дослідноконструкторських робіт; впровадження нових технологій; від інвестиційної діяльності, а також амортизаційні відрахування.

В другому розділі фінансового плану вказуються напрямки використання фінансових ресурсів, наприклад, на створення нових основних фондів, на наукові дослідження та інші витрати; враховуються витрати на капітальні вкладення, відрахування в різні фонди 
тощо.

Третій включає кредитні відносини підприємств 3 банківськими установами; враховуються всі види кредитів, які одержані підприємством, їх повернення, виплата відсотків за користування кредитом.

В четвертому розділі відбиваються взаємовідносини підприємства 3 бюджетом та позабюджетними фондами; складається дохідна та витратна частини: у витратній фіксуються податкові платежі в бюджет та позабюджетні фонди, а в дохідній - грошові надходження на відновлення виробництва. Фінансове планування діяльності повинно постійно орієнтуватись на запити та умови фінансування проектів, забезпечуючи мобільність потоків грошових коштів відповідно до потреб інноваційного підприємства.

Контроль $є$ важливим елементом в системі фінансування інновацій і має забезпечити раціональність використання всіх видів ресурсів, своєчасність проведення фінансових операцій, доцільність залучення окремих підрядних організацій та інших учасників інноваційного процесу.

Висновки даного дослідження i перспективи подальших робіт у цьому напрямку. На залізничний транспорт припадає більше половини всього вантажообігу, тому з розвитком залізниць пов'язані інші галузі економіки. Крім того, залізничний транспорт $є$ досить матеріаломістка та енерговитратна галузь, де впровадження інновацій 3 метою економії витрат може дати значний ефект, перш за все, в масштабі країни.

Фінансування проектів у необхідних обсягах покликано забезпечити сталий інноваційний розвиток залізничного транспорту, нарощення науково-технічного потенціалу галузі 3 метою підвищення конкурентоспроможності залізниць на ринку транспортних послуг. Для налагодження чіткої системи фінансування необхідно визначати основні джерела фінансування або їх сукупність, розробити механізм акумуляції грошових надходжень та раціональні методи інвестування інноваційних проектів, а також механізм контролю за використанням коштів та оцінку його ефективності.

\section{ПЕРЕЛІК ВИКОРИСТАНИХ ДЖЕРЕЛ}

\section{1. Дикань, В.Л. Забезпечення} ефективності інноваційної діяльності підприємств залізничного транспорті: монографія / В.Л. Дикань, В.О. Зубенко. Х.: УкрДАЗТ, 2008. - 194 с.

2. Економіка i організація інноваційної діяльності на залізничному транспорті: навч посібник / В.Л. Дикань, О.Г. Кірдіна, І.Л. Назаренко, Ю.М. Уткіна; за ред. В.Л. Диканя. - Харків: УкрДАЗТ, 2014. - $314 \mathrm{c}$.

3. Зубенко, В.О. Забезпечення ефективності інноваційної діяльності на підприємствах залізничного транспорту / В.О. Зубенко, Л.Ю. Коник // Вісник економіки транспорту і промисловості. 2015. - №49. - C. 177-180.

4. Калініченко, Л.Л. Вирішення інвестиційної проблеми інноваційного розвитку підприємств залізничного транспорту / Л.Л. Калініченко // Економіка: проблеми теорії та практики: Збірник наукових праць. - Дниіпропетровськ: ДНУ, 2008. - Випуск 236, Т.2. - С. 222-227.

5. Кірдіна, О.Г. Пріоритетність інвестиційно-інноваційних проектів на залізничному транспорті [Електронний ресурс] / О.Г. Кірдіна // Ефективна економіка: електронне наукове фахове видання. - 2011. - №2. - Режим доступу: http://www.economy.nayka.com.ua/?op=1\&z= 467

6. Дикань, В.Л. Модель інноваційного конгломерату, як інструменту забезпечення конкурентоспроможності національної мережі МТК / В.Л. Дикань, А.В. Толстова // Вісник економіки транспорту i промисловості: Збірник наук. праць Харків, УкрДАЗТ, 2010. - №31. - С. 13-18.

7. Кірдіна, О.Г. Інтеграційні процеси та задачі інвестиційно-інноваційного

Вісник економіки транспорту і промисловості № 59, 2017 
розвитку залізничного комплексу / О.Г. інвестиційні системи залізничного Кірдіна // Вісник ХНАУ - 2010. - №11. - С. транспорту: становлення та розвиток / В.П. 189-201. Ільчук. - К.: Логос, 2004. - 381 с.

8. Ільчук, В.П. Інноваційно-

\title{
УДК 658.589:656.2
}

\section{ОРГАНІЗАЦІЙНО-РЕСУРСНЕ ЗАБЕЗПЕЧЕННЯ ІННОВАЦІЙНОГО РОЗВИТКУ ПІДПРИЕМСТВ ЗАЛІЗНИЧНОГО ТРАНСПОРТУ УКРАЇНИ}

\author{
Токмакова I.B., д.е.н, професор, \\ Зубов А.М., здобувач (УкрДУЗТ)
}

В статті визначено, щуо процеси активізації інноваційної діяльності та забезпечення інновачійного розвитку вітчизняного залізничного транспорту трунтуються на потенщіалі системи організаційно-ресурсного забезпечення. Розкрито складові системи організаційно-ресурсного забезпечення інноваційного розвитку на підприємствах залізничного транспорту, зокрема виділено організаційно-управлінську, фінансово-економічну, матеріально-технічну, кадрову, інформаційно-знаннєву компоненти та маркетингово-логістичну компоненти. Зроблено висновок щзодо актуальності впровадження на підприємствах залізничного транспорту системи управління знаннями як метаресурсом інноваційної діяльності.

Ключові слова: інновацї̈, розвиток, організаційно-ресурсне забезпечення, управління, підприємства залізничного транспорту.

\section{ОРГАНИЗАЦИОННО-РЕСУРСНОЕ ОБЕСПЕЧЕНИЕ ИННОВАЦИОННОГО РАЗВИТИЯ ПРЕДПРИЯТИЙ ЖЕЛЕЗНОДОРОЖНОГО ТРАНСПОРТА УКРАИНЫ}

\author{
Токмакова И.В., д.э.н, профессор,
} Зубов А.Н., соискатель (УкрГУЖТ)

В статье определено, что процессы активизации инновационной деятельности $u$ обеспечения инновационного развития отечественного железнодорожного транспорта основываются на потенциале системы организационно-ресурсного обеспечения. Раскрыто составляющие системы организационно-ресурсного обеспечения инновачионного развития на предприятиях железнодорожного транспорта, в частности выделено организаџионно-управленческую, финансовоэкономическую, материально-техническую, кадровую, информационно-знаниевую и маркетингово-логистическую компоненты. Сделан вывод об актуальности внедрения на предприятиях железнодорожного транспорта системы управления знаниями как метаресурсом инновационной деятельности.

(C) Токмакова I.B., Зубов A.M.
Вісник економіки транспорту і промисловості № 59, 2017 